\section{Flapjack or jackboot? Reflections on leadership styles for the COVID-19 pandemic}

\author{
Sir David Dalton
}

I remember watching my mum baking flapjacks and being intrigued by the label on the golden syrup tin: a picture of bees flying out of a lion with the caption: 'Out of the strong came forth sweetness'. This memory was prompted when I was reading a book review last weekend on Machiavelli and the philosophy of leadership-the exercise of strength and power-which is attributed to him. The rather odd juxtaposition has played on my mind at a time when I know colleagues are facing one of the biggest challenges of leadership in the National Health Service (NHS).

Some of my earlier management experiences were shaped by a culture of performance management when the centre made demands down the organisational chain. Career progression in part was based on the extent to which you acceded to the demands and supplied what was requested. I am simplifying, but the phrase 'just get a grip' was widely used and 'having a grip' was admired.

Many NHS leaders learnt how to survive, and some learnt how to thrive, using the levers of power and control to achieve their ends. Machiavelli might have smiled when some CEOs began to pay attention and 'man-mark' their CEO colleagues, because they were concerned that the success of a colleague organisation might diminish their own power base. There were times when it seemed that in some places the NHS was becoming gridlocked-where change was being resisted even though that change would have been for the greater good of the population.

Of course, there were the nonconformists-people who were prepared to think and act differently. Spurred by a belief in people and in their inherent goodness, they were encouraged by the messaging from people like Kanter, ${ }^{1}$ Berwick $^{2}$ and West. ${ }^{3}$ A new understanding was being formed by the experience of the improvement and behavioural scientists. Some CEOs began to engage their workforce differently-handing power

\section{Correspondence to}

Sir David Dalton, Dalton Consulting, Manchester, UK; david@daltonconsulting.net back into their organisations, aware that the ideas for change would be found deep inside them. Collaborative and compassionate leadership was seen to work, it was getting results that were being sustained in a way that a command and control culture was never able to do.

It is my observation and belief that leaders of organisations have preferred styles: to either hold on to the power which their position gives them, or to share this power with others. These are not binary choices, but we all have a tendency to lean more in one direction than another. The former preference relies on a strong belief in oneself, and the capability to determine solutions to problems which you get people to adhere to. The latter preference comes from a genuine belief that sharing positional power with others is more likely to generate better ideas and get greater commitment to change.

The COVID-19 pandemic has required the establishment of effective chains of command-rightly so. As Gold and Silver command centres are established, staff are being required to comply with multiple top-down instructions. Managers are attempting to minimise ambiguity and ensure that policy is adhered to. The public is also consenting to strong national leadership in this crisis. The media, quick to spot gaps and inconsistencies, is prompting the need for authoritative statements and positions.

Yet I hope that the need for strong leadership is not misunderstood, by leaders, as a requirement to assert themselves on those whom they lead. Kind, compassionate leadership is the sweetness that needs to come from strength. It is sometimes too easy for leaders to rely on positional power, and become disconnected from their people, and not see the distance between them increasing-until it is too late.

Visibility of leadership has always been essential-no more so than now. The pandemic is challenging leaders to find new ways to 'do visibility' without always being physically present. This is so important, as being situationally aware is vital: leaders must be aware of the extraordinary pressure and suboptimal circumstances that staff are working in. Providing empathy and understanding is crucial when staff need to know, more than ever, that their leaders care about them. This means resisting the temptation to explain why things have to be the way they are, and instead finding the time first to listen to the frustrations people experience.

Encouraging kindness by rolemodelling it yourself is the true strength of leadership-recognising that the power that you have is only really given to you by the consent of the people you lead. In exchange, it is possible to receive the one thing which cannot be commanded-the discretionary effort, the extra contribution that could otherwise be withheld.

Our good leaders are comfortable with 'power and control'; our best leaders are the ones who know how to share this appropriately with their staff. I hope very much that during the unprecedented pressures that our leaders will face, they will always show respect, compassion and kindness towards their staff.

As I reflect on my own understanding of leadership philosophy, I see two divergent paths based on these quotes: 'power is the pivot on which everything hinges. He who has power is always right; the weaker is always wrong'; ${ }^{4}$ and 'out of the strong came forth sweetness'. 5 The possession of power brings with it both opportunities and temptations-let us hope that the choice and desire of leaders in, and after, the pandemic is to reach for another flapjack, and not for the jackboot!

Contributors DD is the sole author and there are no other contributing authors.

Funding The authors have not declared a specific grant for this research from any funding agency in the public, commercial or not-for-profit sectors.

Competing interests None declared.

Patient consent for publication Not required.

Provenance and peer review Commissioned; externally peer reviewed.

Author note DD Former CEO, Salford Royal NHS FT and the Northern Care Alliance. Currently Chair of AQuA, Chair of the Association of NHS Groups, and Director of Dalton Consulting.

This article is made freely available for use in accordance with BMJ's website terms and conditions for the duration of the covid-19 pandemic or until otherwise determined by BMJ. You may use, download and print the article for any lawful, non-commercial purpose (including text and data mining) provided that all copyright notices and trade marks are retained.

(C) Author(s) (or their employer(s)) 2020. No commercial re-use. See rights and permissions. Published by BMJ. 


\section{Editorial}

\section{Check for updates}

To cite: Dalton SD. BMJ Leader 2020;4:99-100.

Received 21 April 2020

Accepted 23 April 2020

Published Online First 18 May 2020

BMJ Leader 2020:4:99-100.

doi:10.1136/leader-2020-000270

\section{REFERENCES}

1 Kanter RM, Moss Kanter R. Power failure in management circuits. Harv Bus Rev 1979;57:65-75.

2 Berwick D. A promise to learn - a commitment to act. independent report into patient safety, department of health and social care, 2013. Available: https://assets. publishing.service.gov.uk/government/uploads/system/ uploads/attachment_data/file/226703/Berwick_Report. pdf

3 M W, Eckert R, Collins B, et al. Caring to change - how compassionate leadership can stimulate innovation in healthcare. London: Kings Fund, 2017. https:// www.kingsfund.org.uk/sites/default/files/field/field_ publication_file/Caring_to_change_Kings_Fund_May_ 2017.pdf

4 This quote is widely attributed to Niccolo Machiavelli but its precise attribution is unclear.

5 Lyle's Golden Syrup tin, quoting from Judges 14:14, King James Bible. Available: https://www. kingjamesbibleonline.org/Judges-14-14/ [Accessed 19 Apr 2020]. 